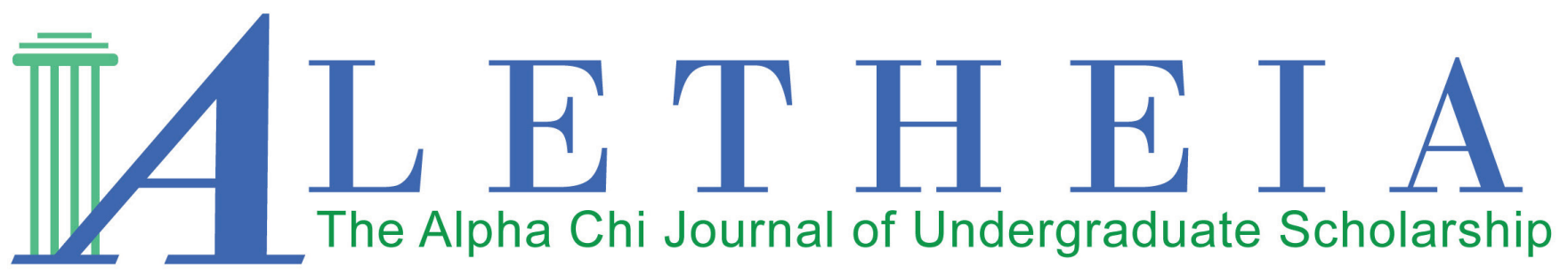

Volume 1 | Issue 2 | 2016

\title{
Grendel's Mother: The Deviant Other in Beowulf
}

\author{
Cheri D. Molter \\ Methodist University \\ North Carolina Mu Chapter
}

Vol. 1(2), 2016

Article Title: Grendel's Mother: The Deviant Other in Beowulf

DOI: $10.21081 / \mathrm{ax} 0051$

ISSN: 2381-800X

Key Words: Beowulf, Grendel's Mother, patriarchy, Hrunting, Othering, deviance This work is licensed under a Creative Commons Attribution 4.0 International License. Author contact information is available from the Editor at editor@alphachihonor.org.

\section{Aletheia-The Alpha Chi Journal of Undergraduate Scholarship}

- This publication is an online, peer-reviewed, interdisciplinary undergraduate journal, whose mission is to promote high quality research and scholarship among undergraduates by showcasing exemplary work.

- Submissions can be in any basic or applied field of study, including the physical and life sciences, the social sciences, the humanities, education, engineering, and the arts.

- Publication in Aletheia will recognize students who excel academically and foster mentor/mentee relationships between faculty and students.

- In keeping with the strong tradition of student involvement in all levels of Alpha Chi, the journal will also provide a forum for students to become actively involved in the writing, peer review, and publication process.

- More information and instructions for authors is available under the publications tab at www.AlphaChiHonor.org. Questions to the editor may be directed to editor@alphachihonor.org.

\footnotetext{
Alpha Chi is a national college honor society that admits students from all academic disciplines, with membership limited to the top 10 percent of an institution's juniors, seniors, and graduate students. Invitation to membership comes only through an institutional chapter. A college seeking a chapter must grant baccalaureate degrees and be regionally accredited. Some 300 chapters, located in almost every state, induct approximately 12,000 members annually. Alpha Chi members have been "making scholarship effective for good" since 1922.
} 


\title{
Grendel's Mother: The Deviant Other in Beowulf
}

\author{
Cheri D. Molter \\ Methodist University \\ North Carolina Mu Chapter
}

\begin{abstract}
In Beowulf, Grendel's mother defies Anglo-Saxon cultural norms, particularly in regard to gender, and lives outside societal boundaries until her death. According to de Beauvoir's The Second Sex, the women mentioned in Beowulf are categorized as the "Other" simply because of their common femininity. However, Grendel's mother defies the Anglo-Saxons' idea of proper feminine behavior through her association with Cain's kin, her active pursuit of revenge for Grendel's death, and her ownership of a battle hall. Thus, she is the "Other" who refuses to assume the role of a passive peace-weaver; she is the unnamed deviant who inverts the status quo of the warrior code as a masculine domain. Beowulf is unable to defeat Grendel's mother as he planned-with Hrunting, the named heirloom sword that had won many heroic victories without a defeat prior to this battle. Perhaps Hrunting fails to kill Grendel's Mother because Beowulf cannot "gain glory" from killing her; or, possibly, she is impervious to Hrunting because of her deviant, unnamed "Otherness." Additionally, a comparison of the stories of Queen Modthryth and Grendel's mother reveals society's attempt to reemphasize patriarchal ideology once the threat to man's definition of femininity is vanquished. Grendel's mother's lack of a name emphasizes her status as an outsider who defies categorization. Only an unnamed sword that preserves the story of the giants - other outcasts from the world of men - can kill her. Grendel's Mother is the "Other" and too deviant; her existence is too threatening even to be recognized by name.
\end{abstract}

Key words: Beowulf, Grendel's Mother, patriarchy, Hrunting, Othering, deviance

In Seamus Heaney's translation of Beowulf, several codes of conduct determine the proper behavior for people based on their gender. A hospitality code determines the correct actions and responsibilities of hosts and guests; a warrior code designates the proper way in which men may pursue glory through treasure-seeking adventures and warfare; and a domestic code determines the appropriate behavior for women as passive peace-weavers who remain in the home. These codes construct boundaries in which to live and assign gender roles. Once a person dismisses these boundaries and roles, the individual could be perceived as a threat to the society as a whole, whether residing in civilization or liv- ing as an outcast in the wilderness. Such is the case of one of Beowulf's adversaries, Grendel's Mother; she is an unnamed woman who does not adhere to society's domestic code for women. Instead, Grendel's Mother exemplifies characteristics of a capable warrior and is free of many of the restrictions imposed on the other women in the poem. Grendel's Mother is the deviant "Other" who inverts prescribed gender codes, fights Beowulf courageously, and dies only from the blow of an unnamed blade that is as alien to Beowulf's society as she is.

According to The Second Sex by Simone de Beauvoir, women are categorized as the "Other" simply as a result of their common femininity. De 
Beauvoir notes that throughout history men have defined humanity as "mankind" and oppressed feminine autonomy to maintain patriarchal dominance: "[Woman] is defined and differentiated with reference to man and not he in reference to her; she is the incidental. . . . He is the Subject, he is the Absolute - she is the Other. . . . Thus humanity is male and man defines woman not in herself but as relative to him; she is not regarded as an autonomous being" (xxii). In Beowulf, Hrothgar calls Grendel's Mother a marauder "from some other world ... [who], as far as anyone ever can discern, looks like a woman," so her appearance of humanity and femininity are acknowledged, although it is clear that Hrothgar is apprehensive to recognize her as either human or feminine (1349-51). Hrothgar's declaration that she is a foreigner and his hesitance to declare her human reveals the multiple ways in which he, as king, publicly names Grendel's Mother "Other." According to him, Grendel's Mother is the "Other" because she "looks like" a woman, and she is demonized as a threat because she does not conform to the societal gender norms; she is alien in origin and nature (1349-51).

Historically, men of Western cultures processed the world around them through binary oppositions - good versus evil, civilized versus wild, and man versus woman. In general, they considered themselves active, strong, adventurous, brave, and intelligent, and they applied the opposite characteristics to women; they decided women were passive, weak, domestic, meek, and simple-minded (de Beauvoir xxviii-xxxi). That perspective supported the framework for the male-dominant ideology that valued and celebrated only that which was familiar and understood by men. Thus, whatever was foreign, mysterious, or physically different was to be destroyed, banished, or oppressed in an attempt to maintain control. De Beauvoir explains, "Being men, those who have made and compiled the laws have favored their own sex, and jurists have elevated these laws into principles. ... Legislators, priests, philosophers, writers, and scientists have striven to show that the subordinate position of woman as the Other is willed in heaven and advantageous on earth" (xxviii). Even the highly esteemed philosopher Aristotle declares that "[t]he female is female by virtue of a certain lack of qualities [and] we should regard the female nature as afflicted with a natural defectiveness" (qtd. in de Beauvoir xxii, emphasis in the original). His statement affirms to a male audience the patriarchal ideology of feminine inferiority, cementing the boundaries around all women as the "Other" long before Anglo-Saxon culture thrived.

Many years after Aristotle's death, the Christian church sanctioned and institutionalized patriarchal ideology, as did other religions, and women continued to be "Othered" throughout many regions of the world. In Beowulf, the biblical story of Cain is discussed in several sections; Hrothgar, Beowulf, and their men categorize Cain as the evil "Other," someone they believe God does not want men to emulate: "Branded an outlaw, marked by having murdered, [Cain] moved into the wilds, shunned company and joy" (1263-65). Unlike Grendel, who is said to be an evil descendent of Cain, Grendel's Mother is described as pagan because of an unclear association with Cain after God banished him from His land (Beowulf 1259-67). While Wealhtheow, Hrothgar's wife and queen, is the "Other" merely because she is a woman, Grendel's Mother poses a multi-faceted threat as the "Other" because she is foreign, mysterious, and a woman.

Not only is Grendel's Mother the "Other," but she also deviates from what is expected of the "Other." In her essay "The Structural Unity of Beowulf: The Problem of Grendel's Mother," Jane Chance writes, "The role of woman . . . primarily depends upon 'peace-making,' either biologically through marital ties with foreign kings as a peace-pledge or . .. socially and psychologically as a cup-passing and peace-weaving queen within a hall" (156). This is evident at the feast after Grendel's death; Wealhtheow passes a cup from man to man, in the order acknowledged by his rank, and speaks publicly of her expectations of her kin to protect her sons' claim to Heorot and its throne (Beowulf 612-28, 1168-89). 
However, this prescribed role of femininity does not apply to Grendel's Mother. Since she is referred to as Cain's, or possibly Cain's descendant's "monstrous hell-bride," she cannot act as a peace-weaver through marriage; the newly Christian Anglo-Saxons would not make an alliance with those who were supposedly banished by God (Beowulf 1259). In Anglo-Saxon society, this gendered role of peace keeping and weaving "becomes a boundary marker between the heroic, martial world of men and the private, domestic world of women" (Wodzak 254). These marked boundaries are clear in the portrayal of the actions of Wealhtheow as Hrothgar's queen, but, despite her femininity, Grendel's Mother lives as an outcast beyond the boundary marker between the codes of behavior. According to Victoria Wodzak, "Passivity [and] sociality. . . belong to the domestic worker; aggression, anti-sociality, and passion to the heroic world. ... The domestic and the heroic domains oppose each other" (257). By this definition of gendered domains, Grendel's Mother has more of the characteristics of the masculine hero than she does the feminine domestic, which defies the Anglo-Saxon idea of proper feminine behavior.

Within Beowulf, there is a myth in which men master a misbehaving woman until she succumbs to the pressure to conform to the role of passive peace weaver. This cautionary tale of admonishment describes the "terrible wrongs" done by Queen Modthryth, her transformation to acceptable feminine behavior after her marriage to "brave Offa," and the moral that "[e]ven a queen outstanding in beauty must not overstep like that. A queen should weave peace, not punish the innocent with loss of life for imagined insults" (Beowulf 1932, 1948, 1940-3). The myth is included after Grendel's Mother's death and reveals the vulnerability of the hierarchy created by mankind. The message of female acceptance of male domination is paramount; it is the patriarchal equivalent of "happily ever after," naturalizing the social hierarchy for the survival of a patriarchal culture. Queen Modthryth is remembered in Anglo-Saxon myth because she conformed to what the society expected her to be, whereas Grendel's Mother is immortalized notoriously as the nameless, dehumanized, passionate adversary who is killed by the epic hero because her story does not support the Anglo-Saxon ideology of feminine roles.

Beowulf's poet may have wanted to stress Grendel's Mother's breach of feminine conduct and her manly capabilities with the language he used to write the epic. From an original transcript of $\mathrm{Be}$ owulf, Jane Chance deciphers the words associated with Grendel's Mother a bit differently than Heaney, and the differences are telling. Chance states:

[S] he is specifically called a wiff unhȳre 'a monstrous woman,' and an ides āglæcwīf 'a lady monster-woman.' Ides elsewhere in Beowulf denotes 'lady' and connotes either a queen or a woman of high social rank. ... In addition, as if the poet wished to stress her maternal role, she is characterized usually as Grendel's mōdor or kinswoman . . . a word almost exclusively reserved for her, although other mothers appear in the poem. It seems clear from these epithets that Grendel's Mother inverts the Germanic roles of the mother and queen, or lady. (155)

Grendel's Mother is called "monstrous" by a presumably male poet not because she is an actual animalistic monster, but because she is a woman who publicly adopts elements of the masculine warrior code, which threatens to falsify the patriarchal norm that women are subordinate peace weavers. She is assertive, strong, and brave; thus, from the male perspective, she is a terrifying anomaly - a monster. Grendel's Mother is their "Other" as a woman, but she is also an alien outcast because she has deviated from the socially constructed role for women.

Unlike Anglo-Saxon men, Grendel's Mother is not motivated to participate in the warrior code by the pursuit of glory. Instead, she seeks revenge for the death of her son, which is traditionally the re- 
sponsibility of men "in a society whose martial law demands either Wergild, [monetary compensation for the death of a kinsman,] or vengeance" (Wodzak 256). Beowulf's poet describes her motives clearly: "[Grendel's] mother has sallied forth on a savage journey, grief-racked and ravenous, desperate for revenge" (1276-78). She, like any mother, cares about her son and mourns his loss. However, she does not remain passive in her grief. After Grendel's Mother attacks Heorot, Hrothgar says, "[N]ow this powerful other one arrives, this force for evil driven to avenge her kinsman's death" (1338-40, emphasis added). This statement is interesting for several reasons. Hrothgar confirms that this feminine "Other" is powerful, and he acknowledges that she acts as a force for evil [Grendel] instead of a force of evil. Hrothgar affirms her humanity and comprehends - but does not condone-why she has acted as she has because he is a warrior who lives by the code she has adopted. In the midst of Grendel's Mother's battle with Beowulf, the poet writes, "So she pounced upon [Beowulf] and pulled out a broad, whetted knife: now she would avenge her only child" (1545-7). The poet reminds the reader of her character as a mother after portraying her as an assertive, strong warrior who is defending her life and domain against Beowulf's attack.

Grendel's Mother has ruled as the "lord" of her hall for many years, which also sets her apart from other women. Legally, a woman was not permitted to be the master of her own hall. According to Frances and Joseph Gies in their book Women in the Middle Ages, "early Anglo-Saxon law codes followed the Germanic tradition in treating women as property, with wives purchased from their families" (19). Historically, anyone seen as property could not own anything of her or his own, so Grendel's Mother's ownership of and mastery over her home inverts the norm. Chance explains that "[b] ecause the poet wishes to stress this specific inversion of the Anglo-Saxon ideal of a woman as both monstrous and masculine, he labels her domain a 'battle-hall' (nïdsele, 1513; gūdsele, 2139)" (155). Also, Grendel's Mother is independent, without a man to govern her, which contradicts what society has deemed a woman capable of:

[W]omen were considered incapable of looking after their own interests . . . [and were] regarded ... as perpetual minors, under the guardianship of a male relative whose permission was needed for any transaction involving property. Saxon Law, written down in 785, contained [these] provisions: a widow became the ward of her deceased husband's nearest male relative. (Gies and Gies, 17)

Grendel's Mother appears to be capable of taking care of herself; while fighting her, heroic Beowulf is frightened by her strength. The poet writes:

[Beowulf] pitched his killer opponent to the floor but she rose quickly and retaliated, grappled him tightly in her grim embrace.

The sure-footed fighter felt daunted, the strongest of warriors stumbled and fell.” (1540-5)

Grendel's Mother is a stronger, braver adversary than Grendel; Beowulf is hard-pressed to kill her (1501-5, 1545-49). The poet states, "[Beowulf] would have surely perished ... had the strong links and locks of his war-gear not helped to save him" (1550-3). Beowulf only survives his confrontation with Grendel's Mother because of the body armor he wears for protection.

Although Beowulf kills Grendel's Mother, he is not able to do so according to his plan. Before facing her in her hall, Beowulf declares, "With Hrunting I shall gain glory or die" (1490). Hrunting is the named heirloom sword that carries the success of many "heroic feats" without the tarnish of a single defeat (1464). According to J. R. Hall, in a "passage as polished as the sword it describes ... we [learn] from whom Beowulf received the sword, the sword's name, and tails [sic] of its material excellence and martial history" (12-13). However, despite Hrunting's treasured status, in battle 
with Grendel's Mother, "the shining blade refused to bite. It spared her and failed the man in his need" (1523-5). Perhaps Hrunting fails to kill Grendel's Mother because Beowulf cannot "gain glory" from killing her (1490). After Beowulf decapitates Grendel's Mother, the emphasis is placed back on to the demise of Grendel, who lies dead in his mother's hall. Beowulf cuts off the head of Grendel's corpse and brings it back to Hrothgar's hall with him as a warrior's trophy (1586-1659). Strangely, despite Grendel's Mother being a more challenging opponent than her son, Beowulf leaves the "doomed house of [Grendel's Mother's] flesh" in her hall; it is not through his victory over her that he can obtain honor. It appears that to attempt to glorify that battle is to admit the vulnerability of mankind and the inaccuracy of the patriarchal claims of femininity (1567-68). Or, possibly, Grendel's Mother is impervious to Hrunting, the treasured extension of the glory of warrior men, because of her deviant, unnamed "Otherness." Her lack of a name, whether a factual namelessness or the poet's deliberate omission in an attempt to further dehumanize her, emphasizes her deviant status as an outsider who does not conform to society's gender roles. She exists outside the parameters of all that is considered normal and good with a nameless identity that defies categorization. Thus, men have only limited power over her, they fear what they cannot control, and their weapons of honor cannot threaten her because they are the extensions of the warrior code she inverts. It takes an unnamed, ancient sword that belongs in the deviant woman's armory and preserves the story of the giants - other outcasts from the world of men - to kill Grendel's Mother, a worthy adversary in a feminine form (Beowulf 1687-98).

Grendel's Mother is the unnamed deviant from the feminine domestic code, refusing to assume the role of a passive peace-weaver or meek matron; she is the "Other" who defies the status quo of the warrior code as an exclusively masculine domain. To attempt to glorify her death is to admit that women are stronger, smarter, and more capable than men had proposed, thus threatening society's masculine values. Instead, the poet writes of a banished, deviant woman who cannot be mastered by man, and who has no value to society. Thus, her death helps solidify the superiority of the Anglo-Saxon cultural values of the time. Grendel's Mother is the "Other" and too deviant; her existence is considered too threatening to even be recognized by name.

\section{Works Cited}

Beowulf: A Verse Translation. Trans. Seamus Heaney. Ed. Daniel Donoghue. New York: W.W. Norton \& Co., 2002. Print.

Chance, Jane. "The Structural Unity of Beowulf: The Problem of Grendel's Mother." In Beowulf: A Verse Translation. Ed. Daniel Donoghue. New York: W.W. Norton \& Co., 2002. Print. 152-67.

de Beauvoir, Simone. The Second Sex. New York: Vintage Books, 1989. Print.

Gies, Frances and Joseph Gies. Women in the Middle Ages. New York: Crowell Co., 1978. Print.

Hall, J. R. "The Sword Hrunting in 'Beowulf': Unlocking the Word 'hord." Studies in Philology 109.1 (2012): 1-18. Web. 27 June 2016.

Wodzak, Victoria. "Of Weavers and Warriors: Peace and Destruction in the Epic Tradition." Midwest Quarterly 39.3 (1998): 253-62. Academic Search Complete. Web. 24 Oct. 2014. 